\title{
Adina Merenlender: Building a new mode of extension for biodiversity conservation
}

W hen UC ANR conservation biologist Adina

Merenlender launched the California Naturalist

program in 2012, she was looking to do more than just educate people. She wanted to build a community inspired to be stewards of the natural world and to push for the resources and policies needed to defend the state's threatened biodiversity.

"Success to me," Merenlender said on an afternoon walk through the oak woodlands of the Hopland Research and Extension Center (REC), "is when the public connects directly with what UC has to offer and will go to bat for UC gardens, reserves and presses, and call for more faculty to study and teach natural history."

Today, the program is blossoming. More than 1,500 participants have completed a California Naturalist course. The program now has a full-time academic coordinator, Greg Ira, and has received grant funding from the National Science Foundation and the California Wildlife

The California Naturalist program encourages participants to engage in research, environmental monitoring and restoration work. Here, California Naturalists explore trace fossils with geologist Ed Clifton at Point Lobos State Natural Reserve in Monterey County.

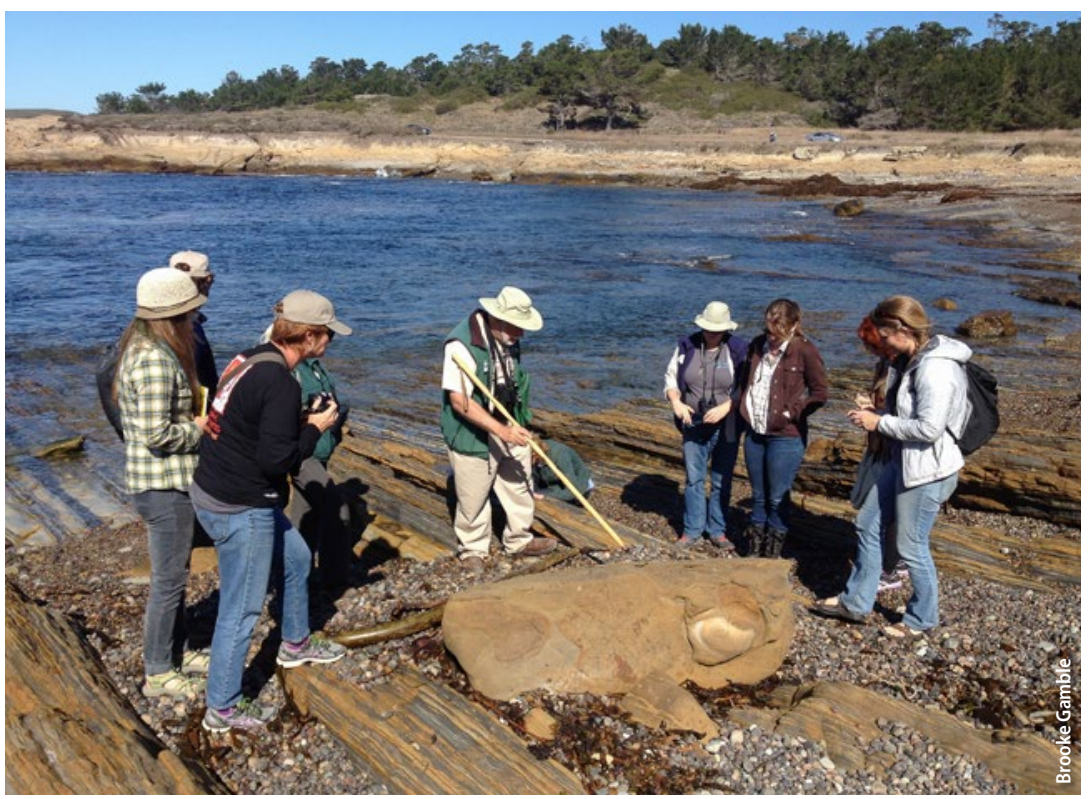

Conservation Board, and in 2015 was honored as the program of the year by the national Alliance of Natural Resource Outreach and Service Programs. The second statewide California Naturalist conference is scheduled for September 9-11 at the Pali Mountain Center in the San Bernardino Mountains.

Through partnerships with more than 30 science and environmental education organizations

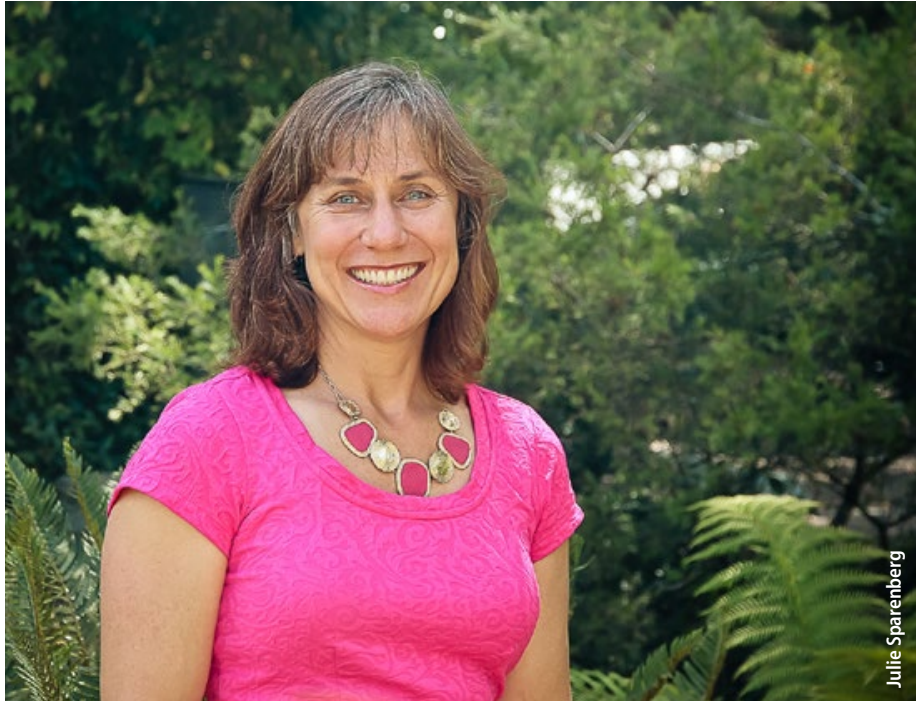

Adina Merenlender, founder and director of the UC ANR California Naturalist program, is a UC ANR Cooperative Extension specialist in conservation biology based at the Hopland Research and Extension Center and an adjunct professor in the Department of Environmental Science, Policy and Management at UC Berkeley.

around the state, the California Naturalist program provides 40-hour certification courses focused on natural history as well as stewardship and communication. The training encourages California Naturalists to volunteer around the state with natural resource agencies and nonprofit organizations, and participants are encouraged to engage in research, environmental monitoring, restoration work and education and outreach.

"The desire to learn about natural history is insatiable," Merenlender said. "We're giving motivated people a way to help out."

The mix of science and action that characterizes the California Naturalist program mirrors the 20year UC ANR career of Merenlender, a Cooperative Extension (UCCE) specialist based at Hopland REC and an adjunct professor of environmental science, policy and management at UC Berkeley.

The threat that development poses to intact natural landscapes has driven Merenlender's work since her early years with UC ANR. In the late 1990s, Merenlender and her collaborators used satellite land-cover data to track and project the rapid expansion of vineyards in Sonoma County (Merenlender 2000). In calling out this agricultural growth as a threat to habitat and biodiversity, the work put Merenlender at odds with the powerful wine industry. 
Merenlender stood by the work and her role as conservation biologist trying to change the world - and still does.

"I try to make my work constructive and to offer solutions," she said. "But you do have to daylight the issues."

\section{Mediterranean stream restoration}

Merenlender then led us down to a seasonal creek at Hopland REC that illustrates a related strand of her research the restoration of streams in Mediterranean climate systems.

As part of a long-term study, one section of a creek degraded by early clearing and dredging was fenced in the 1980s to exclude deer and other large herbivores, while an adjacent section was left open.

Standing on the sun-bleached cobbles of the unfenced reach, Merenlender points out the dense vegetation that now covers the fenced area - much as it likely did before the area was settled.

In studying streams like this one, Merenlender and graduate student Jeff Opperman made two findings that have shaped the way stream restoration is conducted in much of California.

First, they determined that woody debris - the key to the pools and varied stream channels that characterize good habitat for native salmonids - is of a different nature in Mediterranean-climate oak woodland systems than in wetter coastal forests. In oak woodland areas like Hopland REC, the woody debris in creeks is generally alive - low branches of oaks, bays, and thickets of willows - while in coastal conifer forests, it is primarily dead wood - fallen trunks and branches.

Their second finding, illustrated by the fence enclosure, was that deer can inhibit the recovery of such ecosystems by eating woody plants before they have a chance to mature to the point where they can provide shade and the important woody debris.

Together, these results shifted the approach to stream restoration in Mediterranean ecosystems: Instead of introducing large woody debris, as is done in coastal evergreen forests, the focus is on creating conditions that allow stream vegetation to

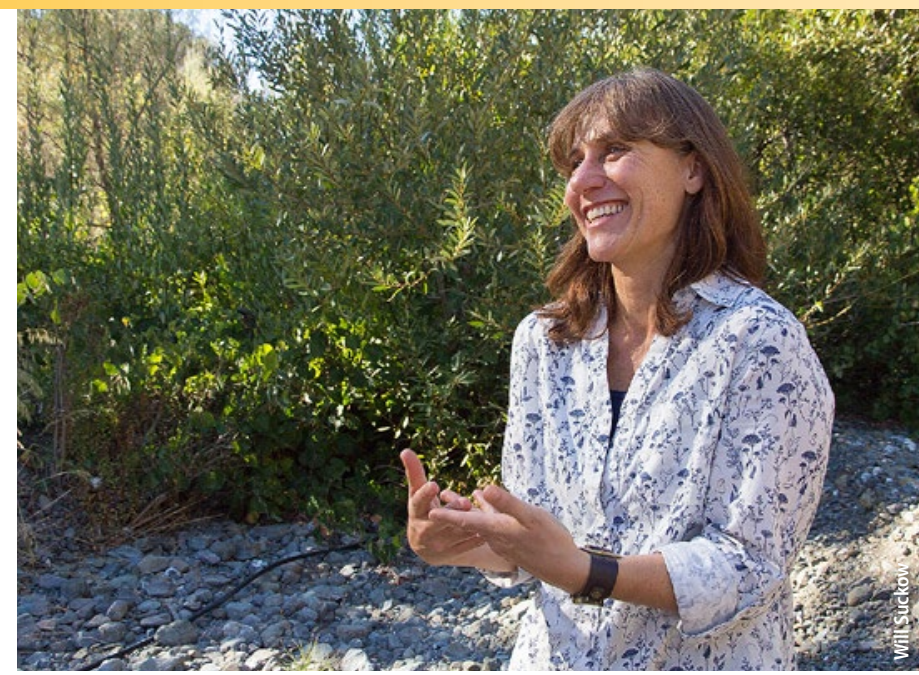

Research by Merenlender and her collaborators has helped to transform the practice of stream restoration in Mediterranean climates.

regenerate, providing important shade, and helping to restore stream morphology for improved salmon habitat.

\section{Rethinking agricultural ponds}

Merenlender's work on vineyard expansion and stream restoration then came together in a body of research, conducted with several graduate students and other collaborators, that shifted the politics of grapes, fish and water in wine country.

It began with several studies of the role of water quantity in salmonid recovery in Mediterranean-climate watersheds (Christian-Smith and Merenlender 2010) and the impacts of upstream water use - from vineyards as well as rural residential pumping - on summer stream flows and juvenile salmon survivorship (Grantham et al 2012).

At the same time that her lab reported the collective impact on salmon survivorship of diverting water from streams to irrigate vineyards during the dry season, Merenlender's team provided models that demonstrated agricultural ponds placed correctly don't necessarily impact winter salmon runs as previously thought and should be used where possible to offset
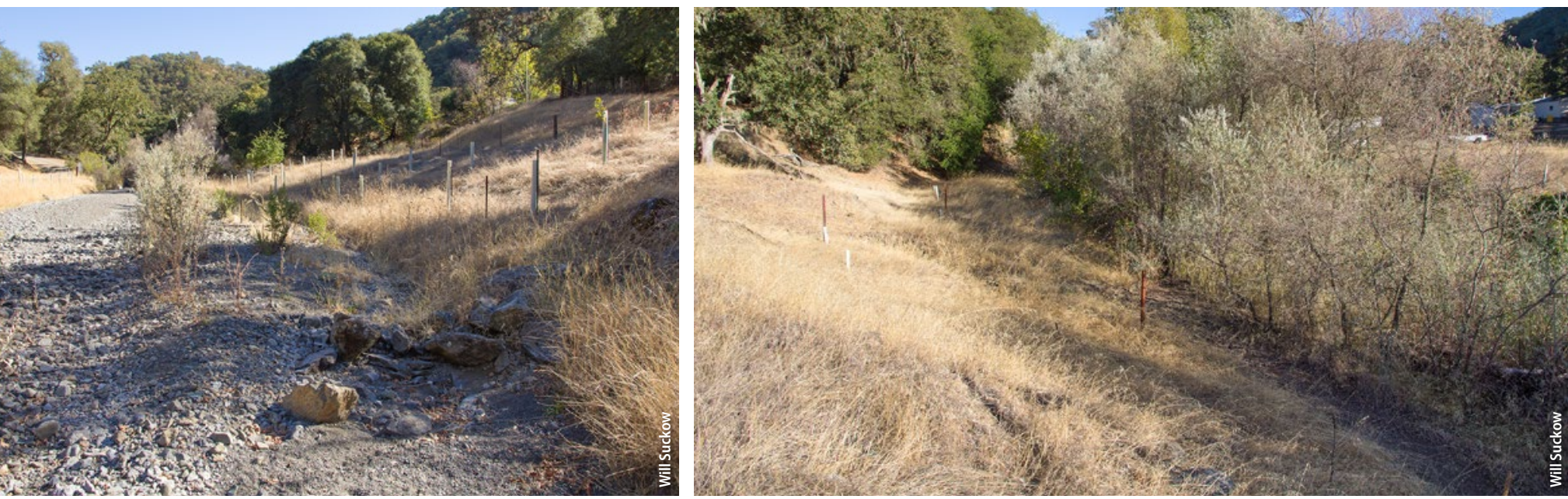

Long-term study sites on Parson's Creek at Hopland REC show the effect of deer herbivory on the recovery of natural cover in a degraded riparian zone. A site not protected from deer, left, has virtually no woody vegetation. By contrast, a site fenced in the 1980s, right, is now densely vegetated, providing shade and helping to form pools, both of which benefit fish. 
summer pumping and thus - in many, though not all, cases provide a benefit to fish (Deitch et al 2013).

This finding helped to shift the thinking about farm ponds in the environmental community and among state water regulators, with the practical result that the review process, which was essentially stopped around 1993 due to concern for salmon and litigation by environmental groups, was resumed, allowing farmers to move forward with the permitting process for a new pond.

That work also changed Merenlender's reputation in the wine grape industry. Once seen as an antagonist for trying to stave off habitat conversion, she was invited to speak at grower meetings on water management solutions.

"You have to stick with it long enough that your enemies become your friends," she said.

\section{Half for us, half for them}

But Merenlender still has concerns about the wine grape industry - and about the state of biodiversity conservation more broadly. While wine industry players large and small have embraced the idea of sustainability in their operations, many don't consider the conversion of natural landscapes into vineyards to be a problem, she said. Likewise, for all of California's environmental leadership in areas like reducing greenhouse gas emissions and managing air pollution, the state hasn't made a serious effort to stop the chief cause of biodiversity loss: the development of natural lands for residential and agricultural use.

"When we're talking about habitat, in a state with the most endangered species, we need to be thinking about what E.O. Wilson said: 'Half for us, half for them,'“' she said, quoting the renowned Harvard biologist considered the father of the academic study of biodiversity. "If we're serious about biodiversity, we're going to have to set meaningful targets for conserving California's native ecosystems and manage these ecosystems."

Building support and enthusiasm for that type of conservation is one of Merenlender's hopes for the California Naturalist program. In the coming years, she foresees a day when the California Naturalists will play a role, perhaps through "dayat-the-Capitol" visits to Sacramento. She's also hoping that UC natural resource academics will connect directly with the California Naturalists about their research and information to help stave off a sixth mass extinction - capitalizing on the power of this new community.

"Working with our partnering organizations around the state, we are creating a whole new mode of natural resource extension," she said.
With leadership from Associate Director Sabrina Drill, California Naturalist is dedicated to broadening the California Naturalist community to include more diversity in age, race and income.

One difficulty in raising money for the California Naturalist program is that institutional donors who fund environmental education tend to support only primary and secondary school programs; there's very little support for adult programs. Merenlender thinks that programs targeting young adults is essential.

"That's when you set your compass," she said.

Merenlender grew up in Los Angeles, and didn't have much interaction with the natural world in childhood beyond watching Wild Kingdom on Sunday evenings. She was more than halfway through her undergraduate years at UC San Diego when she got involved in her first conservation biology project, a study of African rhinoceroses.

Today, her research is focused on how conservation efforts can best support biodiversity, for instance by planning for habitat connectivity and the effects of the changing climate. She advises a number of land trusts and public land agencies on systematic conservation planning, and co-authored the first comprehensive book on wildlife corridor planning (Hilty et al 2012).

The threat of extinction is on Merenlender's mind even here in the 5,300 acres of quiet, protected hills and valleys that make up Hopland REC.

Tracyina rostrata, a small flowering annual, is now found only at Hopland REC. The center's staff monitor the known populations of the plant regularly, and its numbers appear to be shrinking.

"We used to have four sites," Merenlender said. "Now it seems to be down to one site. Gulp." CA

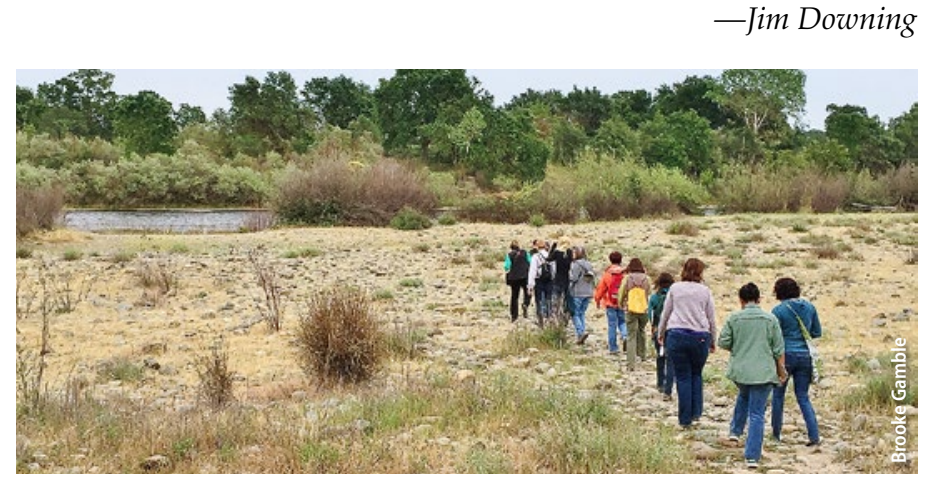

Above, California Naturalists learn about the plants and animals of the American River Parkway at the Effie Yeaw Nature Center near Sacramento.

\section{References}

Christian-Smith J, Merenlender AM. 2010. The disconnect between restoration goals and practices: A case study of watershed restoration in the Russian River basin, California. Restor Ecol 18:95-102. doi:10.1111/j.1526-100X.2008.00428.x

Deitch MJ, Merenlender AM, Feirer S. 2013. Cumulative effects of small reservoirs on streamflow in Northern Coastal California catchments. Water Resour Manag 27:510118.

de Nevers G, Edelman DS, Merenlender A. 2013. The California Naturalist Handbook. Berkeley: UC Press.
Grantham TE, Newburn DA, McCarthy MA, Merenlender AM. 2012. The role of streamflow and land use in limiting oversummer survival of juvenile steelhead in California streams. Trans Am Fish Soc 141:585-98. doi:10.1080/00028487.2012.683472

Heaton E, Merenlender AM. 2000. Modeling vineyard expansion, potential habitat fragmentation. Calif Agr 54:12-9. doi:10.3733/ca.v054n03p12

Hilty JA, Lidicker Jr WZ, Merenlender A. 2012. Corridor Ecology: The Science and Practice of Linking Landscapes for Biodiversity Conservation. Washington, D.C.: Island Press.

Merenlender AM. 2000. Mapping vineyard expansion provides information on agriculture and the environment. Calif Agr 54:7-12. 